\title{
The Interplay between Brain-Derived Neurotrophic Factors and Stress Hormone Modulates the Process of Neurogenesis
}

\author{
Neetu Saini* \\ Department of Zoology and Fishery Sciences, Dolphin PG College of life Sciences and Agriculture ChunniKalan, India
}

Submission: September 17, 2018; Published: October 09, 2018

*Corresponding author: Neetu Saini, Assistant Professor Dolphin PG college of Science and Agriculture Chunni Kalan, FGS, Punjab, Pin-140307, India, Tel: +91-7696242999; Email: dr.nsaini@hotmail.com

\begin{abstract}
Alteration in neurogenesis plays a vital role in etiology of brain disease, including mental disorders and neurodegenerative diseases. The brain-derived neurotrophic factor (BDNF) is a key regulator of neural survival, growth and plasticity involved in emotional and cognitive function. It is a well-known neurotropic factor which is involved in neurogenesis process. BDNF is highly vulnerable to stress. Various evidences show a negative impact of the stress hormone glucocorticoids (GCs) on differentiation and survival of neurons, which is also related to the pathophysiology of brain diseases. This review article has demonstrated functional interactions between neurotropic factors and stress hormone in neurogenesis.
\end{abstract}

Keywords: BDNF; Neurotropic factor; Stress; Glucocorticoids; Neurodegeneration

\section{Introduction}

Brain-derived neurotrophic factor (BDNF) is molecule that enhances the growth and maintenance of neurons in the central nervous system [1,2]. BDNF is highly expressed in the hippocampal and cortical regions of the brain where they involved in neuronal survival, synaptic plasticity and the formation of long-lasting memories [3-5]. Their high affinity receptor, TrkB has been identified as the Trk family of tyrosine protein kinases, thus facilitate to understand the signaling pathways responsible for mediating their trophic properties [6]. TrkB receptor is phosphorylated by binding of BDNF that trigger the activation of ERK-, Akt-, and PLC gamma-pathways [7-9]. Each pathway contributes to multifarious neuronal functions, including neurogenesis and the regulation of cell fate $[10,11]$. Various studies demonstrated that reduced expression of BDNF along with depressive behaviors, suggesting that an alteration in status of the BDNF/TrkB system leads to reduction in neurogenesis resulting brain dysfunctioning. Chronic stress reduces mRNA levels of BDNF [10,12] is one of the most important endogenous mediators of stress responses in the mammalian brain. Glucocorticoids (GCs) a stress hormone, exert influence on neurogenesis and functions, as well as BDNF [13]. Blood levels of GCs are regulated by hypothalamus-pituitaryadrenal (HPA) axis activity [14-16]. It is well known that chronic stress induces the hyper activation of HPA axis, resulting overabundance of GCs levels [16].
Elevated levels of GCs have a role in the onset of mental disorders, including post-traumatic stress disorder, major depressive disorders and neurodegeneration. Furthermore, GC stress suppress the formation of neuron synthesis, especially in hippocampal region, has been a vulnerable target to develop new drugs because it shows the dysregulation of HPA axis function $[17,18]$ and is considered as a culprit that leads to the onset of the mental disorders [19]. This review article demonstrated the functional interaction between BDNF and GCs towards altered neurogenesis.

\section{Impact of BDNF and GCs on Brain}

It is well known that chronic stress affects the neural morphology particularly in the hippocampus and the amygdala brain regions [20]. A single exposure to emotional stress is sufficient to increase dendritic length and number in amygdala region and vice versa in the hippocampus region [21,22]. Moreover, a study suggests that distinctive hippocampal and amygdala neuroarchitecture alteration predicting specific patterns of behavioral disruption following stress exposure in an animal [23]. These findings direct our focusing to understand if these stress effects on brain morphology are mediated by GCs. However, neurotrophic and GCs systems both act in antagonistic as well as in synergistic manners. BDNF and GC are involved in dendritic ramification, usually BDNF is associated with spine 
formation and stabilization with GC rather playing a vital role in spine turnover [3,24]. A study showed that chronic GC administration results in spine loss in the cortex. Interestingly, transient raise in GC levels mostly affected newly formed spines, whereas chronically increased GCs affected spines that have been formed early in life [25].

However, both BDNF/TrkB and GCs/GR systems are occupied in neurogenesis, the interaction between these systems in neurogenesis is of interest. Therefore, this interplay in the neural function, including neurotransmitter release, synaptic structure has been investigated [18]. Many studies demonstrated a negative impact of systemic administration of GCs on BDNF mRNA expression in hippocampal and cortical regions [26-28]. It has been demonstrated that mRNA expression of BDNF was concealed by GC vulnerability via binding of GR to the regulatory sequences of the BDNF gene in neuron-like cells inveterate from mouse [29]. Previous study reported that TrkB also interacted with GR and mediated calcium signaling regulated by PLC gamma [29,30].

\section{Molecular Mechanisms of BDNF and GC Interplay}

BDNF can directly influence the HPA-axis regulation through modification of $\mathrm{CRH}$ expression levels. On the other hand, dexamethasone (DEX, a synthestic GC) administration led to suppression of $\mathrm{CRH}$, which could not be up to the mark by BDNF treatment [3]. A study revealed that DEX treatment stimulates more GR-binding to the $\mathrm{CRH}$ promoter $[3,31]$. In contrast to DEX, BDNF boost cAMP response element-binding protein (CREB) -binding to its site on the $\mathrm{CRH}$ promoter, which is in juxtaposition to the GR-binding site [32]. The central mechanistic element in $\mathrm{CRH}$ regulation is the recruitment of CREB to the $\mathrm{CRH}$ promoter. CREB requires the interaction with a coactivator protein named CREB regulated transcription coactivator 2 (CRTC2) for its transcriptional activity [33]. Upregulated GC levels lead to the relocalization of the nuclear CRTC2 to the cytosol and thus downregulate the CREB transcriptional activity at the $\mathrm{CRH}$ promoter [3]. In additional, another aspect of association between the GC- and BDNF-signaling pathways seems to involve the mitogen-activated protein kinase (MAPK) pathway. Overexpression of MKP-1 induces detrimental effects by obstruct the axonal growth [34]. Regulation of the GC levels and consecutively MKP-1 expression levels proceed towards the restoration of stress-related depressive phenotypes through regulate the BDNF expression [35]. In a further study it was demonstrated that acute GC activity excites transient enhancement in tissue-plasminogen activator protein, which is play a vital role in proteolytic cleavage of pro-BDNF to mature BDNF. The excessive amounts of mature BDNF itself associate with TrkB and trigger downstream MAPK phosphorylation, which is imperative for the emergence contextual fear memory [36].

\section{Conclusion}

This review introduced the functional interplay between the BDNF/TrkB and GCs/GR systems in the neurogenesis. High level of BDNF and low GC levels are involved in neuronal maintenance, synaptic integrity and dendritic spine stabilization in the brain regions. BDNF-GC equilibrium is pivotal throughout life as a considerable mechanism for stress response regulation.

\section{Acknowledgment}

This work was supported by Dolphin PG College of Science and Agriculture, FGS, Punjab, India.

\section{Conflicts of Interest}

The authors declare no conflict of interest.

\section{References}

1. Chao MV (2003) Neurotrophins and their receptors: a convergence point for many signalling pathways. Nat Rev Neurosci 4(4): 299-309.

2. Lu B, Nagappan G, Guan X, Nathan PJ, Wren P (2013) BDNF-based synaptic repair as a disease-modifying strategy for neurodegenerative diseases. Nat Rev Neurosci 14(6): 401-416.

3. Jeanneteau F, Chao MV (2003) Are BDNF and glucocorticoid activities calibrated? Neuroscience 239: 173-195.

4. McEwen BS (2003) Mood disorders and allostatic load. Biol Psychiatry 54(3): 200-207.

5. Edelbrock AN, Àlvarez Z, Simkin D, Fyrner T, Chin SM, et al. (2018) Supramolecular Nanostructure Activates TrkB Receptor Signaling of Neuronal Cells by Mimicking Brain-Derived Neurotrophic Factor. Nano Lett.

6. Ohira K, Hayashi M (2009) A new aspect of the TrkB signaling pathway in neural plasticity. Curr Neuropharmacol 7(4): 276-285.

7. Klein R, Parada LF, Coulier F, Barbacid M (1989) trkB, a novel tyrosine protein kinase receptor expressed during mouse neural development. EMBO J 8(12): 3701-3709.

8. Kryl D, Barker PA (2000) TTIP is a novel protein that interacts with the truncated T1 TrkB neurotrophin receptor. Biochem Biophys Res Commun 279(3): 925-930.

9. Ohira K, Homma KJ, Hirai H, Nakamura S, Hayashi M, et al. (2006) TrkB-T1 regulates the RhoA signaling and actin cytoskeleton in glioma cells. Biochem Biophys Res Commun 342(3): 867-874.

10. Li Y, Wang D, Li Y, Chu H, Zhang L, et al. (2017) Pre-synaptic TrkB in basolateral amygdala neurons mediates BDNF signaling transmission in memory extinction. Cell Death Dis 8(7): e2959.

11. Bibel M, Barde YA (2000) Neurotrophins: key regulators of cell fate and cell shape in the vertebrate nervous system. Genes Dev 14(23): 29192937.

12. Gharami K, Xie Y, An JJ, Tonegawa S, Xu B, (2008) Brain-derived neurotrophic factor over-expression in the forebrain ameliorates Huntington's disease phenotypes in mice. J Neurochem 105(2): 369379.

13. Schoenfeld TJ, Gould E (2013) Differential effects of stress and glucocorticoids on adult neurogenesis. Curr Top Behav Neurosci 15: 139-164.

14. Paragliola RM, Papi G, Pontecorvi A, Corsello SM, et al. (2017) Treatment with Synthetic Glucocorticoids and the HypothalamusPituitary-Adrenal Axis. Int J Mol Sci 18(10).

15. Zhu LJ, Liu MY, Li H, Liu X, Chen C, et al. (2014) The different roles of glucocorticoids in the hippocampus and hypothalamus in chronic stress-induced HPA axis hyperactivity. PLoS One 9(5): e97689.

16. Herbert J (2013) Cortisol and depression: three questions for psychiatry. Psychol Med 43(3): 449-469. 


\section{Current Trends in Biomedical Engineering \& Biosciences}

17. Raglan GB, Schmidt LA, Schulkin J (2017) The role of glucocorticoids and corticotropin-releasing hormone regulation on anxiety symptoms and response to treatment. Endocr Connect 6(2): R1-7.

18. Gray JD, Milner TA, McEwen BS (2013) Dynamic plasticity: the role of glucocorticoids, brain-derived neurotrophic factor and other trophic factors. Neuroscience 239: 214-227.

19. Furay AR, Bruestle AE, Herman JP (2008) The role of the forebrain glucocorticoid receptor in acute and chronic stress. Endocrinology 149(11): 5482-5490

20. McLaughlin KJ, Gomez JL, Baran SE, Conrad CD (2007) The effects of chronic stress on hippocampal morphology and function: an evaluation of chronic restraint paradigms. Brain Res 1161: 56-64.

21. Pinheiro RM, de Lima MN, Portal BC, Busato SB, Falavigna L, et al. (2015) Long-lasting recognition memory impairment and alterations in brain levels of cytokines and BDNF induced by maternal deprivation effects of valproic acid and topiramate. J Neural Transm (Vienna) 122(5): 709-719.

22. Rao RP, Anilkumar S, McEwen BS, Chattarji S, et al. (2012) Glucocorticoids protect against the delayed behavioral and cellular effects of acute stress on the amygdala. Biol Psychiatry 72(6): 466-475.

23. Cohen H, Kozlovsky N, Matar MA, Zohar J, Kaplan Z, et al. (2014) Distinctive hippocampal and amygdalar cytoarchitectural changes underlie specific patterns of behavioral disruption following stress exposure in an animal model of PTSD. Eur Neuropsychopharmacol 24(12): 1925-1944

24. Kim H, Yi JH, Choi K, Hong S, Shin KS, et al. (2014) Regional differences in acute corticosterone-induced dendritic remodeling in the rat brain and their behavioral consequences. BMC Neurosci 15: 65.

25. Liston C, Gan WB (2011) Glucocorticoids are critical regulators of dendritic spine development and plasticity in vivo. Proc Natl Acad Sci USA 108(38): 16074-16079.

26. Smith MA, Makino S, Kvetnansky R, Post RM (1995) Stress and glucocorticoids affect the expression of brain-derived neurotrophic factor and neurotrophin-3 mRNAs in the hippocampus. J Neurosci 15(3 Pt 1): 1768-1777.
27. Vellucci SV, Parrott RF, Mimmack ML (2001) Down-regulation of BDNF mRNA, with no effect on trkB or glucocorticoid receptor m RNAs, in the porcine hippocampus after acute dexamethasone treatment. Res Vet Sci 70(2): 157-162.

28. Gourley SL, Kedves AT, Olausson P, Taylor JR (2009) A history of corticosterone exposure regulates fear extinction and cortical NR2B, GluR2/3, and BDNF. Neuropsychopharmacology 34(3): 707-716.

29. Chen H, Lombes M, Le Menuet D (2017) Glucocorticoid receptor represses brain-derived neurotrophic factor expression in neuron-like cells. Mol Brain 10(1): 12.

30. Numakawa T, Kumamaru E, Adachi N, Yagasaki Y, Izumi A, et al. (2009) Glucocorticoid receptor interaction with TrkB promotes BDNFtriggered PLC-gamma signaling for glutamate release via a glutamate transporter. Proc Natl Acad Sci U S A 106(2): 647-652.

31. Miller L, Foradori CD, Lalmansingh AS, Sharma D, Handa RJ, et al. (2011) Histone deacetylase 1 (HDAC1) participates in the downregulation of corticotropin releasing hormone gene (crh) expression. Physiol Behav 104(2): 312-320.

32. Kumamaru E, Numakawa T, Adachi N, Kunugi H, et al. (2011) Glucocorticoid suppresses BDNF-stimulated MAPK/ERK pathway via inhibiting interaction of Shp2 with TrkB. FEBS Lett 585(20): 32243228.

33. Tao X, Finkbeiner S, Arnold DB, Shaywitz AJ, Greenberg ME, et al. (1998) $\mathrm{Ca}^{2+}$ influx regulates BDNF transcription by a CREB family transcription factor-dependent mechanism. Neuron 20(4): 709-726.

34. Duric V, Banasr M, Licznerski P, Schmidt HD, Stockmeier CA, et al (2010) A negative regulator of MAP kinase causes depressive behavior. Nat Med 16(11): 1328-1332.

35. Jeanneteau F, Deinhardt K, Miyoshi G, Bennett AM, Chao MV, et al (2010) The MAP kinase phosphatase MKP-1 regulates BDNF-induced axon branching. Nat Neurosci 13(11): 1373-1379.

36. Revest JM, Le Roux A, Roullot-Lacarrière V, Kaouane N, Vallée M, et al. (2014) BDNF-TrkB signaling through Erk1/2 MAPK phosphorylation mediates the enhancement of fear memory induced by glucocorticoids. Mol Psychiatry 19(9): 1001-1009.

This work is licensed under Creative Commons Attribution 4.0 License DOI: 10.19080/CTBEB.2018.17.555951

Your next submission with Juniper Publishers
will reach you the below assets
- Quality Editorial service
- Swift Peer Review
- Reprints availability
- E-prints Service
- Manuscript Podcast for convenient understanding
- Global attainment for your research
- Manuscript accessibility in different formats
( Pdf, E-pub, Full Text, Audio)
- Unceasing customer service
Track the below URL for one-step submission
https://juniperpublishers.com/online-submission.php

